\title{
AREIAS E CONTAS EM MOVIMENTO: ANÁLISE DE DOIS FILMES DE ANIMAÇÃO
}

CRISTINA BRUZZO*

$\mathscr{P}$ artindo da idéia de Gaston Bachelard de que a manipulação da matéria permite a recriação da realidade pelo imaginário poético, ${ }^{1}$ proponho uma divagação a respeito de dois filmes de animação, ${ }^{2}$ nos quais o manuseio da matéria pelo animador tem um papel fundamental. Isto parece óbvio, afinal o filme de animação se apresenta como uma seqüência de imagens que criam a ilusão de movimento e estas imagens são construídas uma a uma como uma forma de expressão na qual as escolhas estéticas são fundamentais, incluída a opção dos suportes e substâncias empregadas. Entretanto, nestes filmes em particular, além do resultado visual proporcionado pelo trabalho artístico do animador, a natureza dos elementos utilizados participa da construção das significaçoes.

A matéria que o animador manuseia tem características singulares que determinam as possibilidades expressivas, como a forma de movimento dos personagens, ao mesmo tempo em que constitui o limite da expressão, porque os diversos tipos de materiais possíveis de serem empregados em filmes de animação não se equivalem. Entretanto, algumas vezes e sob determinado aspecto, elementos diferentes podem ser equiparáveis.

Assim podemos considerar a areia semelhante a contas de vidro, não esquecendo suas diferenças. A aproximação proposta considera duas características destacadas por Elias Canetti em sua análise da areia como unidade coletiva que pode ser percebida como um símbolo de massa: ${ }^{3}$ a pequenez e a infinitude. A areia é composta por partículas cujo peque-

Professora da Faculdade de Educação da Unicamp, pesquisadora do Laboratório de Estudos Audiovisuais (OlHo).E-mail: bruzzo@unicamp.br 
no tamanho apaga as particularidades e, por isso, são percebidas como um conjunto homogêneo, padronizado em sua imensa quantidade. $\mathrm{O}$ movimento da massa de areia apresenta uma certa fluidez que pode ser entendida como um "meio caminho entre o líquido e o sólido: são as nuvens e tempestades de areia". Percebido como movimento e som, é o vento que dá ordem à areia, neste caso entendendo-se os dois sentidos da palavra ordem: arranjo metódico do conjunto e também como comando. $\mathrm{O}$ vento organiza o deslocamento da areia em alguma direção: desmanchando arranjos existentes para conformá-la de outro modo, no incessante mudar das dunas; na possibilidade de retirar cada partícula de areia de seu estado de repouso. A inércia geralmente associada ao deserto, percebido como o espaço onde nada acontece, é quebrada pelas tempestades de areia, quando o movimento e o som do vento expressam sua fúria.

Pelo seu tamanho diminuto e pela sua quantidade, qualquer extensão de areia permite questionar a delimitação entre contínuo e descontínuo. A areia é formada por grãos, mas sua soma apresenta certos comportamentos de quase continuidade, como a água cujas gotas se juntam na massa que chamamos mar ou oceano, movendo-se ordenadamente em ondas, ou deixando-se estar em aparente imobilidade, de todo modo impossibilitando a contagem e a ordenação numérica.

Demiurgo, o animador Co Hoedeman reflete a condição de manipulador da areia, utilizando-a em seu filme de animação e nele criando um personagem (um homem de areia?) que utiliza a areia para criar outros seres. $\mathrm{O}$ filme começa com um deserto de areia submetido à ação do vento. Quando o vento se acalma, da areia emerge um "homenzinho" que começa a criar outras formas, seres que terminam sua própria construção, dando os retoques finais; outros surgem, meio sem origem precisa. Estes seres de areia empenham-se na construção de um castelo, seguindo o plano do "homenzinho" inicial. A cada qual uma função precisa na construção e um tipo de dança após a satisfatória conclusão do trabalho. A areia mostra-se dócil e passiva, submissa à manipulação, até que, tudo pronto, outra ordem se impõe. O vento começa a soprar e a areia soterra o castelo e seus habitantes, restabelecendo a paisagem inicial. O caráter cíclico do filme permite esperar que os seres, protegidos no interior do castelo que estiveram construindo, venham a emergir da areia, mesmo porque não há indícios de que seres de areia possam ser por ela sufocados. A ação e as danças recomeçariam. Tudo também pode ser apenas uma brincadeira, entre formas variadas da areia, solta e agregada em combinações ilusórias que buscamos nomear - homem, estrela do mar, cobra - na enganadora analogia das formas vivas conhecidas. 
Mas a imagem final lembra um deserto de areia e como tal assinala uma interrupção da ordem, a destruição da paisagem construída, ainda que temporária e até mesmo apenas soterrada, mas subtraída à visão do espectador. ${ }^{4}$ Esta destruição, causada pela pequenez e infinitude dos grãos movidos pelo vento, indicaria a derrota do demiurgo/homem frente aos elementos naturais? Parece que o vento pode mais e faz isto mobilizando diminutas partículas cuja inércia altera, de forma ordenada, em contínuo movimento na mesma direção. Assim o descontínuo se faz contínuo, pelo deslocamento dos grãos que resulta na constituição de um espaço que podemos supor homogêneo.

A desagregação das rochas, pela ação do vento e da água, produz a areia, cuja composição depende da natureza da rocha original. Algumas areias se prestam à fabricação de vidro, aquelas com grande concentração de sílica, que, submetidas a altas temperaturas e depois resfriadas, formam esta estranha substância amorfa e homogênea, viscosa, quebradiça e, por suas características físico-químicas, incluída na categoria dos líquidos. Podemos submeter a areia ao fogo, outro elemento natural que pode ordenar a matéria, instaurando a aparente desordem da combustão das substâncias orgânicas e ordenando a transmudação dos minerais. Com esse procedimento obteremos fazer contas de vidro.

As contas, também diminutas, aproximam-se da areia, ao serem reunidas em grande quantidade. Não têm, é claro, a infinitude da areia, porém podemos pensar nas contas como gotas (a palavra inglesa sead contém os dois sentidos). Tal como areia vista em grande aumento, as contas deslizam umas sobre as outras, movendo-se em resposta às forças exteriores, desmanchando formas. Um deserto de contas como um mar de areia.

Contudo, é possível pensar nas contas como pontos, pontos ampliados e coloridos, translúcidos como um líquido. Pois é como pontos que as contas aparecem no filme de Ishu Patel..$^{5}$ As contas alinhadas, em ordem, formando retas e curvas, desenham o contorno dos seres que se sucedem em transformaçóes progressivas. Esta relação com pontos se evidencia no final pela alternância das contas com linhas desenhadas. Os seres que se metamorfoseiam também se apresentam em ordem, alinhados numa sequência temporal, do mais simples ao homem, a evolução biológica que se entrelaça com o desenvolvimento da tecnologia bélica, desembocando no poder destrutivo do átomo. Esta ordenação permite estabeler uma continuidade entre o instinto de caça e a destruição guerreira. $\mathrm{O}$ espírito bélico estará inscrito em nossa natureza biológica? A utilização das contas como pontos grandes ressalta o caráter descontínuo, em contradição com a natureza contínua da linha que se 
busca simular. Porém, ao incorporar total ou parcialmente em cada novo ser as contas que formavam o corpo do anterior, ampliando sua quantidade, é como se as contas se fundissem e separassem num amálgama de cores e brilhos que instaura uma continuidade.

Ishu Patel montou um didático panfleto pacifista. A escolha das contas permite a analogia com o átomo, pequena unidade no meio da infinidade de similares, formando um contínuo da matéria visível, como uma linha de contas e cuja ação, em série, amplifica o poder de destruição. Contudo, será que, ao estabelecer toda esta cadeia de similaridades, este movimento contínuo das contas formando linhas, que constituem seres que se incorporam nos seguintes, o animador não sugere também uma continuidade entre o instinto animal e o desejo de poder e conquista do homem civilizado, construtor de bombas?

Patel acredita que o homem é lobo do homem, como queria Hobbes? Devemos buscar na natureza a moralidade que funda a sociedade humana? Esta visão antiutópica do futuro da civilização é uma realização admirável, um belo trabalho de movimento, cor e forma, entretanto uma sugestão perigosa ao naturalizar a racionalidade bélica, que inventa armamentos cada vez mais poderosos para "não serem utilizados", armando a lógica preventiva que supóe o tutoramento da paz pelos "xerifes" de boa vontade.

Essas contas, que se combinam e recombinam, engolem e permanecem, também podem, sendo areia e vidro, ser átomos em desatino, entre tantas pequenezas ao mesmo tempo contínuas e descontínuas, tal como os genes, colares de contas da grande cadeia dos seres. ${ }^{6}$

Podemos pensar na vingança dos elementos: areia e vento, contas e átomos. Também cabe supor que sob a areia se mantiveram todos os seres de Co Hoedeman, aguardando acalmar-se o vento. Também a cama de gato que o homem faz com a linha de contas entre seus dedos, no final do filme de Patel, é um jogo que admite continuidade.

Mas se pensarmos na areia/conta como símbolo de massa, conforme sugere Elias Canetti, a sensação será bem mais incomoda.

O caráter uniforme, gigantesco e inanimado do deserto coloca o homem diante de um poder quase insuperável, um poder composto de incontáveis partículas homogêneas. Tal poder sufoca como o mar, mas de uma maneira mais astuciosa, porque mais demorada.

A relação do homem com a areia do deserto antecipa algumas de suas atitudes futuras: a luta que, com um poder crescente, ele tem de travar contra enormes legiōes de minúsculos inimigos. A secura da areia foi transferida para os gafanhotos. (Canetti, 1995, p. 87) 


\section{Gafanhotos, formigas, chips... incontáveis personagens para outros tantos soterramentos.}

\section{Notas}

1. Para uma breve aproximação, ler a introdução de José Américo Motta Pessanha no volume Bachelard, da coleção Os Pensadores, São Paulo: Abril Cultural.

2. A escolha feita recaiu sobre dois filmes que empregam a técnica de animação de materiais tridimensionais, portanto não são desenhos animados. Sugiro a leitura do texto de Céu D’Elia sobre as técnicas do cinema de animação.

3. "Unidades coletivas não constituídas de seres humanos, mas, ainda assim, percebidas como massas, estas eu as designo símbolos de massa. Unidades assim são o trigo, a floresta, a chuva, o vento, a areia, o mar e o fogo. Cada um desses fenômenos abriga em si qualidades deveras essenciais da massa. Embora não se constituam de seres humanos, eles lembram a massa, representando-a simbolicamente no mito, no sonho, no discurso e na canção" (Canetti, 1995, p. 74).

4. Considero que a definição de Carl Ortwin Sauer para paisagem geográfica amplia o significado do soterramento do castelo. O autor, "em 1925, definiu a paisagem geográfica como o resultado da ação da cultura, ao longo do tempo, sobre a paisagem natural" (Corrêa e Rosentahl, 1998, p. 7).

5. Na verdade, é possível que as contas empregadas no filme sejam de plástico, mas isto não compromete a interpretação, porque visualmente as contas parecem de vidro e a lógica da animação é a ilusão. Da mesma forma, em Castelo de Areia, os bonecos foram construídos com massa de modelar e uma estrutura de arame para possibilitar a movimentação, mas eles parecem de areia.

6. Donna Haraway aborda os genes como entidades autotélicas e auto-referenciais (Haraway, 1997).

\section{Referências bibliográficas}

CANETTI, Elias. Massa e poder. São Paulo: Companhia da Letras, 1995.

HARAWAY, Donna. Modest_witness @ Second_Millennium.FemaleManÓ Meets_OncoMouseÔ: Feminism and Techoscience. Roudledge, 1997.

CORREA, Roberto Lobato; ROSENDAHL, Zeny (Orgs). Paisagem, tempo e cultura. Rio de Janeiro: EDUERJ, 1998.

D’ELIA, Céu. Animação, técnica e expressão. Coletânea Liçôes com cinema: Animação. São Paulo: FDE, 1996.

\section{Filmografia}

\section{Castelo de areialLe château de sable/The sand castle (1977), de Co Hoedeman.}

Histoire de Perles/Sead games (1977), de Ishu Patel. 